\title{
UNIVERSITYOF BIRMINGHAM

\section{Oxfam and the problem of NGO aid appraisal in the 1960s}

\author{
Hilton, Matthew
}

\author{
License: \\ None: All rights reserved \\ Document Version \\ Peer reviewed version
}

Citation for published version (Harvard):

Hilton, M 2018, 'Oxfam and the problem of NGO aid appraisal in the 1960s', Humanity, vol. 9, no. 1.

<http://humanityjournal.org/issue9-1/oxfam-and-the-problem-of-ngo-aid-appraisal-in-the-1960s/>

Link to publication on Research at Birmingham portal

Publisher Rights Statement:

This document is an unedited draft, not for citation accepted for publication in Humanity.

Final Version of record published in Vol 9, Issue 1 at: http://humanityjournal.org/issue9-1/oxfam-and-the-problem-of-ngo-aid-appraisal-in-the1960s/

\section{General rights}

Unless a licence is specified above, all rights (including copyright and moral rights) in this document are retained by the authors and/or the copyright holders. The express permission of the copyright holder must be obtained for any use of this material other than for purposes permitted by law.

-Users may freely distribute the URL that is used to identify this publication.

- Users may download and/or print one copy of the publication from the University of Birmingham research portal for the purpose of private study or non-commercial research.

- User may use extracts from the document in line with the concept of 'fair dealing' under the Copyright, Designs and Patents Act 1988 (?)

- Users may not further distribute the material nor use it for the purposes of commercial gain.

Where a licence is displayed above, please note the terms and conditions of the licence govern your use of this document.

When citing, please reference the published version.

Take down policy

While the University of Birmingham exercises care and attention in making items available there are rare occasions when an item has been uploaded in error or has been deemed to be commercially or otherwise sensitive.

If you believe that this is the case for this document, please contact UBIRA@lists.bham.ac.uk providing details and we will remove access to the work immediately and investigate. 


\title{
Oxfam and the problem of NGO aid appraisal in the 1960s
}

\author{
Matthew Hilton \\ $\underline{\text { University of Birmingham }}$
}

In 1968 the humanitarian and development charity Oxfam asked a simple question: does aid work? What this meant in practice was that it appointed its first Aid Appraiser. Bernard Llewellyn's job was to visit and report on various Oxfam projects around the world and come to a clear decision as to whether he believed the organisation's money had been well spent. On his own, working as an early pioneer of rudimentary project evaluation within the NGO sector, he was unlikely ever to answer the larger question about the effectiveness of development that has, and continues to be, asked of the aid sector more generally. But in this essay I want to explore what happened when one aid agency asked the question of itself and examine the internal dynamics of the responses to reports of success or failure. As anthropologists such as James Ferguson and David Mosse have noted, the most important question to ask of development is less whether projects work and more how they are claimed to do so: that is, there is a 'social life' to aid appraisal, how success is 'produced' and how reports are received and interpreted by various institutions and actors with a stake in the development infrastructure. ${ }^{1}$

At the time of Llewellyn's appointment, NGOs were still relatively minor players in a global system of development dominated by the United Nations and bilateral assistance. Since then, and especially from the 1970s, the number and size of NGOs has expanded almost exponentially. There has been growing interest in whether their more local, grassroots initiatives have proved more effective mechanisms for assisting some of the very poorest communities in the world. Do NGOs Make a Difference? is the straightforward title of one such volume devoted to the topic, though the question itself lies at the heart of a burgeoning literature on the role of the voluntary and charitable agencies. ${ }^{2}$ Indeed, measuring the effectiveness of aid has become an area of expertise in itself, with guidelines and training programmes appearing for a growing professional body of aid appraisers. ${ }^{3}$

Ferguson's investigation of how aid works on the ground famously pointed to the systems of governance at work in which the true beneficiaries of the aid regime are not the imagined poor recipients but all those with an interest in the maintenance of the machinery of aid itself. His analysis has been extended such that NGOs have become implicated within the 
systems of governmentality at work within developmentalism. NGOs have been charged with having done less to reduce poverty and more to promote technocratic, global norms and liberal values as modern-day missionaries. ${ }^{4}$ In one of the few historical studies of aid and development NGOs, Gregory Mann further suggests that organisations like Oxfam were incorporated into what he has termed 'the road to nongovernmentality' from the 1970s onwards. ${ }^{5}$ In this essay, I want to suggest that we might identify such tendencies even earlier and that the dynamics within organisations themselves - as opposed to the wider institutional infrastructure of the developmental machinery - promoted a similar tendency to selfperpetuation. How Oxfam responded to self-critique shows us that the capacities for organisations to engage in self-assessment, absorb criticism, expand and maintain a positive vision of their future direction were evident as soon as appraisal began.

The 1960s were a crucial period in the history of aid. It was the time of the UN's First Development Decade, and the moment when NGOs, previously committed principally to short-term humanitarian emergencies, forged a place for themselves within the professional world of long-term development. It was also a moment when criticisms of aid and development became more pronounced. From the left, aid was charged with maintaining the economic balance of power in the west, promoting capitalist neo-colonialism or, as Kwame Nkrumah put it, 'the last stage of imperialism'. ${ }^{6}$ And from the right, critics of aid such as Peter Bauer were beginning to focus on what they saw as inappropriate and damaging government intervention in the market which, left alone, would eventually bring economic prosperity to all. ${ }^{7}$ By the end of the decade, the UN did acknowledge the need to hold its various institutions to account. In 1969, R. G. A. Jackson reported on the lack of coordination, waste of funds and absence of appraisal across the entire UN infrastructure, preparing the way for a renewed focus on evaluation at the UNDP during the second Development Decade of the 1970 s. $^{8}$

Oxfam was not immune from such critiques and its creation of the role of Aid Appraiser was but the first of many such appointments that would later be made in the NGO sector. The man it put in place was a career aid worker who had begun as a relief worker in China with the Friends Ambulance Unit and the UN Relief and Rehabilitation Administration before moving on to the Save the Children Fund in Korea. ${ }^{9}$ A dour personality, Llewellyn upset the more enthusiastic voices within the organisation who were less prepared to hear how the money Oxfam had extracted from the British public could often, according to Llewellyn, go to waste. It is precisely these responses to appraisal - newly available in NGO archives - that tell us much about the nature of NGO development policy. No matter how 
much he might tell the organisation it had made mistakes in its operations, or had engaged in enterprises in which the goals and the outcomes were never really articulated or understood, he did little to check Oxfam's inexorable expansion or limit its willingness to support an incredibly diverse portfolio of aid programmes. His colleagues could be deaf to his declarations of failure and waste of funds. Always hopeful that money raised in good faith would be spent effectively by those who meant well, their optimism overshadowed Llewellyn's occasionally glum findings. Eventually, he was to call this the 'Oxfam bias', articulating more prosaically what future scholars would describe as the self-perpetuating logic of the governmentality of aid.

In what follows, the first section traces the debates over aid appraisal within Oxfam throughout the 1960s, during a period of rapid expansion and some radicalisation of the organisation. A second section then details how individuals within the organisation responded to the reports of the Aid Appraiser. As David Mosse has argued, studies of the depoliticising effects and consequences of the aid machinery too often ignore the human voices and agency within and across institutions. Actors deliberately chose to re-articulate project evaluations in what amounted to a 'social construction of success' and which in turn served to maintain the support structures for those corners of development which diverse individuals had an interest in defending. ${ }^{10}$ This article does not claim to offer a comprehensive account of nongovernmental aid programmes at the end of the UN's first development decade. What it does is draw attention to the internal dynamics of one organisation that provides clues to how NGOs spurred themselves on to the ambitious plans for growth and expansion that would be realised in future decades. Internally, NGOs operated their own systems of governance which seemed at times to resemble a confederacy of optimists. That is, while each individual had his or her own areas of concern and professional interests to protect, all shared a faith in the essential worth of their organisation. While NGOs facilitated the increasing professionalization of their work in all spheres, they also always ensured that hope triumphed over despair. In this sense, growth and expansion were almost the inevitable consequences of the internal logic of the assessment of aid.

\section{Aid appraisal and the decade of development}

The significance of the UN's first Development Decade of 1960s was not only for the official, technocratic machinery of aid infrastructure associated with inter-governmental organisations. It also served as a catalyst for voluntary organisations, charities, and NGOs 
around the world. Bodies such as the UN Food and Agriculture Organisation (FAO) became concerned not only with prestige economic and technical infrastructure projects but also with meeting the needs of the hungriest people. Particularly through the Freedom From Hunger Campaign (FFHC), launched in 1960, the FAO aimed to raise awareness of development issues among the global public and to enrol the voluntary agencies into development projects by supporting agricultural improvement schemes. British NGOs - and Oxfam in particular were enthusiastic backers of the Campaign. As additional funds reached the coffers of the leading NGOs, they searched for new projects around the world and soon created an impressive portfolio of grassroots schemes that transformed the nature of their purpose and goals. ${ }^{11}$ By the end of the decade, the British NGO sector had been transformed. Oxfam's income alone grew from less than $£ 10$ million (adjusted for inflation) before the launch of the FFHC, to over $£ 30$ million by $1970 .{ }^{12}$ Moreover, as well as the transformation of the agencies from short-term humanitarian relief charities into long-term development NGOs, the sector as a whole found its political voice. Oxfam and Christian Aid led the way in radicalising the sector. The charities spoke collectively through advocacy bodies such as the Voluntary Committee on Overseas Aid and Development (VCOAD), set up as the main point of liaison with the Ministry of Overseas Aid from 1965, through campaigns such as the Haslemere Declaration of 1968 calling for more official funding, through run-ins with the Charity Commissioners as they seemed to overstep their charitable remit with their more collective political pronouncements, and through the establishment of new pressure groups such as the World Development Movement in 1969. ${ }^{13}$

Such rapid changes inevitably brought tensions within organisations as the recruitment of new, younger staff led to impatient demands for faster and more radical change. Oxfam created a position of deputy director and made the ambitious appointment of an outspoken campaigning clergymen, the Rev Nicholas Stacey. He very publicly resigned from the organisation in 1970 when he felt the pace of change was still insufficient. In a letter published in the national press he complained that he felt compelled to leave as he did not 'fancy [him]self primarily as a fund raiser'. ${ }^{14}$ Yet the younger staff nevertheless continued to push not only for an expansion of field operations (Oxfam was not yet 'operational' itself on the ground at this stage, still preferring to fund the work of others), but also for still further collaboration at home with the likes of Christian Aid and War on Want.

The younger staff were often up against the generation of trustees and employees who had been with the organisation since its early years, some all the way to 1942, and who could express scepticism at the pace of change across the sector. Bernard Llewellyn, although only 
joining the organisation in 1958, was very much a part of this older spirit. A former Methodist and conscientious objector, he had become impressed with the work and compassion of the Quakers during his time in China. The lessons he learned there had an indirect influence on how Oxfam operated, not least because in China Llewellyn came across Michael Harris and Ken Bennett, two other volunteers with the Friends Ambulance Unit who also went on to work with Oxfam. Indeed, it meant Oxfam's first three Overseas Aid Directors (Llewellyn, Bennett, Harris), covering the period all the way up to the early 1980s, were all products of a 'unique grounding' provided by the Quaker FAU in China. ${ }^{15}$ For Llewellyn, but also others within the organisation, it meant that throughout all the trends in later long-term development thinking, at the core of his humanitarian conscience would persist a commitment to hands-on emergency relief work, especially that provided by volunteers motivated above all by compassion and with little knowledge of the wider political complexities that lay behind the causes of suffering.

Amidst this potential for conflict between an older generation who placed limits on the role of the humanitarian and the younger, modern aid workers who wanted to speak out on so many other issues there was actually strong agreement that assessing the impact of aid was important. As Oxfam began to embark on new ventures through Freedom From Hunger they all acknowledged that some rudimentary assessment was required of where and how the extra funds were being spent and to what ends. Given his experience of actual relief work on the ground - a skill in relatively short supply in many a NGO - Llewellyn soon found himself being flown around the world to report on Oxfam's increasingly diverse range of projects. It was not long before he was calling for the proper appraisal of projects both at the outset and upon completion. He quickly concluded of a visit to Austria in 1961, for instance, that 'all aid programmes are easier to start and to continue than to stop or change'. ${ }^{16}$ He was aware that there was often a mismatch in the charitable field between the 'inadequacy' of the written requests from organisations outshined by those better at 'selling projects' to donors such as Oxfam. ${ }^{17}$ Closer control was required. Payments were made yet few checks were carried out and the failure to provide reports was often overlooked. ${ }^{18}$ Agencies did not co-ordinate. As a consequence, donations might be made according to the whim of the funder rather than the needs of the recipient. In Algeria in 1962 he was particularly appalled to find an unused German Red Cross operating theatre. ${ }^{19}$ Reports of a crisis, as he felt of Hong Kong in the same year, could misrepresent what was taking place thereby misdirecting funding and leading to the 'embarrassment' of the government of the affected communities. ${ }^{20}$ 
Returning to Asia in 1964 as Field Director for the entire region, he found many 'monuments to human folly and wasted aid'. ${ }^{21}$ Back in Korea he remained 'depressed by the ease with which this country soaked up foreign aid to so little purpose'. The massive aid programmes failed to prioritise appropriately while Oxfam, 'filling in the gaps left by the bilateral aid programmes', and in trying to support so many missions and local initiatives was 'blown about by contrary winds and opinions'. ${ }^{22}$ In Pakistan, he gloomily concluded that the milk powder distributed in aid packages usually ended up in the tea houses through the black market. $^{23}$

Llewellyn remained a forceful advocate for the traditional recipients of Oxfam's funds, though he warned too of those who showed a little too much 'faith in Providence'. ${ }^{24}$ He cautioned too over the willingness to work with the official aid programmes and with host governments. He suspected, for instance, that many of the agricultural schemes launched through FFHC had absolved the late colonial state of some its responsibilities, especially in the High Commission Territories of southern Africa. ${ }^{25}$ He believed the rapid expansion of the aid sector in the 1960s had even influenced the approach to natural disasters. For instance, he felt the reporting of the East Pakistan cyclone tragedy in late 1965 was terribly exaggerated, fuelled by the eagerness of the British charities to showcase their ability to respond. ${ }^{26} \mathrm{He}$ knew that pointing out all these pitfalls might achieve little as others would dismiss his 'cynicism or world-weariness' but he believed it vital for the staff at the aid agencies to keep their feet on the ground amidst this rush to expand all over the world. ${ }^{27}$

This is not to argue that he was opposed to the grandiose aid programme when he felt it necessary. He remained enough of a technocrat to realise that in countries such as India a massive mobilisation of effort would be required to re-orientate the entire country's agricultural and distribution systems. Later, he would become an advocate of integrated development schemes. The key to all was good planning and the clear articulation of objectives. The smaller scale, more realisable projects that he was predisposed towards could then be brought together as a more coherent whole, in which the overall goals were set out in advance. What he did not want was forcibly expressed in a frustrated letter he wrote to Oxfam's Director, H. Leslie Kirkley, in 1965:

Of course Oxfam has a contribution to make - but in doing its primary job, not in this guise of a glorified Honey Bee buzzing hither and thither, meddling in this and that, rather like an overgrown Lady Bountiful acting as a catalyst wherever possible, stirring up jealousies in other groups who are not so ubiquitously busy both saving the world and other organizations from themselves. Just 
who do we think we are? . . . What's coming over you, Oxfam? Where's the business mind and approach which I once found so refreshing after long years of doing good. . . [W]e go to committees with arguments charged with emotive platitudes that may or may not be true, are scarcely specific enough to contradict, sound highly principled enough to command support, and give people who are not too clear what it is all about the feeling that, even if the United Nations is not looking too healthy, there is always Oxfam ready to step into the breach. ${ }^{, 28}$

For Llewellyn, the solution lay in a clearer set of guidelines as to what Oxfam's policy on aid actually was. This, he believed, had to be set out according to measurable criteria that could be later assessed with some degree of accuracy and with the expectation that conclusions could be drawn as to whether objectives had been met. After firing off a whole series of memos, reports, and responses, Oxfam finally accepted his point and appointed him Aid Appraiser in 1968. ${ }^{29}$

For all that Llewellyn's own methods of aid appraisal were self-taught, often instinctual and certainly amateurish compared to the later levels of skill and expertise exercised within the evaluation profession, the appointment was significant for the time. His frank admissions stood out amidst the more positive and upbeat tones adopted by other visitors to the field. Staff from headquarters would generally visit a great number of projects over a period of 2-4 weeks. They would be quickly shown around a scheme by a local field director or project manager and they would come away sufficiently swayed to recommend the continuation or extension of funding. They would then be whisked off to the next project and at the end of their visit they would set out a few conclusions that emphasised how Oxfam's work was perfectly sound. Some occasionally admitted there to have been one or two exceptions, though their reports, with the exception of Llewellyn's, were written to leave a confident and favourable impression. ${ }^{30}$ If none went so far as C. M. Carruthers, the field officer for Africa from 1965, that 'Oxfam is a symbol of hope', most were guilty of using similar and not entirely relevant 'emotive platitudes' referred to by Llewellyn in the quotation above. $^{31}$

Llewellyn aimed to work alongside Field Directors, assessing completed projects such that the Field Director could make more informed judgments for the future. He planned to consult technical experts when appropriate, always raise the question of costs, quantify results where possible, make overall judgments and work in collaboration with other tentative forays into appraisal being made by academics consulted by the FFHC (particularly at the LSE, the University of Sussex and the Netherlands Economic Institute at Rotterdam). In the future, he envisioned even more detailed and professional reports being written by outside 
experts. But in 1968 at least, what he felt Oxfam most needed was a single individual prepared to make a 'fairly brusque appraisal' and who had 'a readiness to stick out one's neck and make a judgment rather than sitting astride the fence' ${ }^{32}$

What he therefore established was a rather basic system of appraisal. Projects were classified from ' $A$ ' to ' $F$ ', with 'A' signifying 'excellent use of funds' to ' $F$ ' 'bad use of funds'. He based his judgment on four criteria - effectiveness, efficiency, significance and lessons learned - while creating an additional category of 'UFA' ('Unsuitable for Appraisal'), meaning in his view 'our Oxfam inputs are so lost or the purposes and the achievements of the project so diffused that nobody could fairly judge them'. ${ }^{33}$ Each report Llewellyn produced opened with an overview of the general situation in the country or region visited, in a style not dissimilar to the introductory comments he used to make about the places he visited when he had attempted to become a travel writer. ${ }^{34}$ It was then followed by a summary assessment of each project funded by Oxfam with an accompanying grade. Llewellyn would then end with a summary of 'lessons deriving' before totalling up how much of Oxfam's finances had been devoted to each category of appraisal.

The successes and failures Llewellyn identified could be quite specific to any one project, but the general lessons learned tended to be in keeping with much of what he had expressed previously, both before and after his appointment with Oxfam. He was particularly concerned with projects that had been running for some time but which had either failed to attract local funding or had given little thought to longer term sustainability. ${ }^{35}$ He awarded low grades to schemes where it was not obvious what Oxfam was trying to achieve: a particularly shambolic school feeding scheme in Kenya was judged to be 'a costly attempt to fly before we can walk' ${ }^{36}$ And he argued there was too often a danger that Oxfam's principal effect would be to prop up a weak central government. Britain's total official aid package for Malawi, for instance, had fallen from $£ 6$ million in 1964 (the year of independence) to just $£ 2$ million. The Malawi government clearly had little in its own budget for development work and Llewellyn believed Oxfam was being sucked into long term projects from which it could never hope to withdraw. ${ }^{37}$ Here, he was especially appalled by the 'disaster' of the $£ 19,000$ given for the building of a new dining hall and kitchen block at the Magomero Community Development Centre. The building was 'beautifully designed, spacious, good to look at' but which Llewellyn berated as the 'Malawi version of the Sydney Opera House . . . as a symbol of Oxfam generosity': 'If this can be justified, is there anything that can't? ${ }^{38}$

By way of contrast, he awarded high grades to those schemes which created no lasting financial legacy and which had a very real impact on a precise number of people, such as 
with agricultural education classes in existing schools and a specific medial initiative at a Family Health Centre run by the Anglicans ('I seldom feel that money given to mission hospitals is other than well used'). ${ }^{39}$ And lest it be thought Llewellyn's curmudgeonly appraisals were wholly out of tune with the rest of the staff in Oxfam, it should be noted that he enthused about the 'A'-graded village agricultural experiment of the Ruvuma Development Association in Tanzania, despite identifying a whole series a specific problems. Here he shared in Oxfam's general optimistic embrace of President Nyerere's ujaama philosophy that would ultimately see the charity expend many hundreds of thousands of pounds to questionable ends. ${ }^{40}$

The summary totals of expenditure under each classification that appeared at the end of every report could make for painful reading. So too were the collations he provided at the end of the year. In 1970, for instance, reporting on 66 projects across 3 continents, he found that only 13 had been awarded an 'A' rating. A further 25 received a ' $B$ ' but the rest were spread across the other - unsatisfactory - grades (6 at 'C'; 9 at 'D'; 3 at 'E'; 1 at 'F' and 9 as 'UFA'). ${ }^{41}$ He later added a further 34 projects to his calculations and argued that only projects graded 'A' and 'B' could be regarded as acceptable for an organisation of Oxfam's reputation and standing. He summarised this to mean that only 49 projects (out of 90) could be regarded as 'good'. A further 41 it was necessary to conclude had not been worth the money expended $(£ 208,700)$ or else fell into the UFA category $(£ 173,500)$. As Llewellyn put it, ‘496,000 spent on good projects out of $£ 878,900$ is not enough’. Repeating his apiaristic accusation that Oxfam had become 'a hive of do-gooding activity' in all areas, he concluded 'that the real quality and effectiveness of what we are doing matter less to us than the image of our involvement and ubiquitousness. ${ }^{42}$

It is unsurprising that Llewellyn used these findings to trigger a more general set of reflections on his part about Oxfam's aid policy. He was against the 'ad hoc' approach which had seen Oxfam expand into any country to provide any type of assistance. Instead, he wanted to develop a consistent policy which would force staff at the charity to make real choices about the type of work it wanted to fund. He favoured a more integrated approach to development in which a variety of projects might still be supported but within 'areas of concentration' such that each initiative might work in support of one another over the longer term and aid would not be wasted through being spread too thin to be effective. ${ }^{43}$ But in doing so, the role of the aid appraiser would need to be amended as well. When he took up his post, he had not thought his reports should be used to direct policy within the organisation. Rather, the aid appraiser would merely assess projects determined from above. 
But so problematic had he found Oxfam's aid policy - or what he perceived to be its absence - that he felt obliged to extrapolate from his findings.

\section{A confederacy of optimists}

The whole question of Oxfam's future direction became caught up in how staff within the charity responded to an aid appraiser and his reports. Llewellyn knew that the principal problem with his position was that his colleagues could simply ignore his findings if they so wished. ${ }^{44}$ This realisation coincided with the more general expansion of Oxfam's activities into advocacy work and a more assertive public role on questions of global justice. NGOs were coming into their own on the development landscape, a phenomenon acknowledged in Lester Pearson’s 1969 report for the World Bank, Partners in Development, which estimated that NGOs globally were handling around \$1billion of aid annually. ${ }^{45}$ Llewellyn found himself out of step with these trends and his 'gloomy' appraisals only seemed to isolate his voice further amidst the youthful optimism that appeared to sweep through the organisation and the charitable sector more generally at the end of the 1960s.

With a growing sense of frustration, Llewellyn began to ruminate on the whole ethos of Oxfam and the development machinery generally, offering insights into what might be regarded as the self-perpetuating - and possibly self-interested - nature of the expansive logic of the bureaucracy of aid. He began to ask fundamental questions about the reorientation of Oxfam's role. As field officers sought out ever more projects and functions for Oxfam, he felt they were making up policy on the spot and taking the organisation down paths they had no right to go. It was not clear to him whether they were serving as a 'dynamic catalyst' or an 'inveterate meddler'. Without clear guidelines, they were expanding Oxfam's role without questioning whether, for instance, they were trampling over the work of indigenous voluntary agencies or taking the place of local government and politicians.

In other projects, it was not always clear what the precise level of need was and, in the absence of proper cost-benefit analysis, there was no sense of prioritising certain types of aid over others, since everything was claimed to be effective and all costs and expenditure could be justified. Oxfam had rightly been wary of funding activities that were properly the function of governments but on the ground, as Llewellyn put it, 'our actions speak louder than our reservations'. ${ }^{46}$ He thought it entirely understandable that Ministries supplemented their own meagre resources when Oxfam made the funds so easily available. Too little 
attention had been given to Oxfam's relationship with indigenous partner organisations with the outcome being that Oxfam funds were being used to expand agencies rather than meet the original need. He found numerous examples of types of project that showed poor results wherever implemented - e.g. school gardens - yet Oxfam kept giving money to support these wherever it could. Capital investments had been poorly monitored and planned, with the very worst leading to repeat grants and the creation of what staff at Oxfam commonly referred to as 'bottomless' pits. ${ }^{47}$

At a more general level he argued that Oxfam needed to decide once and for all whether it wished to support types of projects that were known to produce results, or to focus on the most needy in the developing world. The latter were those to which all of Oxfam's publicity claimed it was helping yet much actual funding went to the former and there was even evidence that this could increase inequalities as the very poorest were left further behind. ${ }^{48}$ Moreover, Llewellyn believed it created exactly the type of dependency associated with official aid which he thought Oxfam had tried to avoid. As Oxfam expanded its range of agricultural schemes, especially those which planned for the future rather than relieving suffering in the present, it created a relationship that was 'rather like putting someone in a heart-lung machine. He has to be kept there for as long as it is needed'. ${ }^{49}$

Eventually, he reflected more abstractedly on why it was that both his specific assessments of projects and his more general conclusions were not taken into account by his colleagues to inform policy and practice. ${ }^{50}$ The phrase he employed to get to the heart of the problem was the 'Oxfam bias'. As a harbinger of later 'future positive' tendencies within development policy, he defined the bias as 'the desirability of being optimistic about aid in general and Oxfam's programme in particular so that increased public support may be obtained'. His role as aid appraiser had made him aware of its power and hold over the organisation: 'the bias is constantly reinforced by the inbuilt non-accountability' ${ }^{51}$

Llewellyn knew full well that aid was a risky business and that these risks had to be embraced if one was to do good in an uncertain world. But because of the absence of accountability many projects could claim benefits for themselves which were never put to the test. Thus every project with an advocate in the organisation would find itself supported and argued to be in accord with Oxfam's core mission. This 'optimistic tendency' was then further encouraged by the interconnections between project publicity and funding allocations, the ready amounts of cash the organisation was raising and the willingness of both Oxfam and the public to assume that being seen to be doing good equated with actual effectiveness. This was not to argue that there were no internal controls. Care was taken in the selection of 
projects. But no judgments were made about their relative worth or the perceived benefits measured against the costs expended. Putting it in the language of his own grading system, his conclusion was that 'UFAs are in no way discouraged. ${ }^{, 52}$ Putting it in the language of govermentailty, the logic of governance internal to the institution provided frequent opportunities for those with a stake in a project to make claims for its success.

Lllewellyn knew right from his appointment as Aid Appraiser that he would be a lone voice. His pronouncements would always run up against those who had a personal interest or emotional attachment to the maintenance of a particular project. So while he was given free rein to comment on any project, the actions arising from his findings were constrained. As the Oxfam Executive put it, 'it was important that the Appraiser should not be a dictator' and that his reports would always be 'open to discussion'. ${ }^{53}$ Field Directors were further reassured that they retained the 'formal responsibility' for deciding on new projects, leaving them relatively free to ignore Llewellyn's advice if they so wished. ${ }^{54}$

The effects of such rules on Oxfam practices can be found in the detailed work of the aid bureaucracy. The organisation's Africa Committee, for instance, always expressed its willingness to take on board Llewellyn's observations at the general level, but some member would likewise always find fault with any specific recommendation or conclusion. Malcolm Harper, a field director in Africa with a far cheerier disposition than Llewellyn, followed up a discussion of a set of appraisals for East Africa with a five-page rejoinder sent directly to Ken Bennett, the then Overseas Aid Director. In it, while stating that he agreed with the general findings, he went through every project Llewellyn had assessed offering correctives and counter evidence that painted a less 'gloomy' picture. Instead, he argued variously for more time, for more effort, for more consideration of other voices, for greater clarity from Llewellyn and for the taking into account of less quantifiable evidence that might provide a more positive conclusion. Occasionally, the tone could become petulant. Of Llewellyn's questioning of support for government schemes in Tanzania, Harper responded with the threat: 'perhaps we should withdraw entirely from supporting any Governmental scheme?'55 Elsewhere, he was likely to conclude a report with an impressionistic statement along the following lines: 'I feel that Oxfam can feel generally satisfied with the quality and direction of its assistance.' 56

Numerous examples exist of the objections being raised to Llewellyn's 'depressing' reports. Field Directors in particular were hardly likely to share his scepticism, since anything less than a judgment declaring ‘success', 'value for money' or 'excellence' might later be used to question their own selection of a project in the first place. Others might take a more 
strategic approach, absorbing the criticism, but then making clear that the situation was now different (that is, in the weeks since Llewellyn's visit), and that therefore funding should be continued and even renewed. ${ }^{57}$ At Committee stage, then, Llewellyn's special status as Appraiser could be reduced to just one voice among many others. The logic of bureaucracy then became inherently optimistic as the organisation accepted the criticism but continued to fund an ever-expanding portfolio of projects.

Frank assessments and general consensus about the ineffectiveness of a scheme were far more likely long after it had come to a definite end than when it was still in operation. When yet another new generation of staff arrived in the early 1970s - those who would be attracted to the conscientisation movement of Latin America as a means of poverty reduction - they were more willing to point out the failures of the 'scattered' nature of Oxfam's aid policy of the previous decade. ${ }^{58}$ It was only at this point, for instance, that Llewellyn was able to get Oxfam as a whole to finally accept that its flagship project in India, the gramdan land reform movement, had been beset by many of the same mismatches between developers' aims and recipient interests that occurred in many a failed project of the UN's technical assistance programme. ${ }^{59}$

Yet this generation too would in turn become committed to the more concentrated forms of assistance provided in countries such as Tanzania. Even when staff began to know of President Nyrere's use of force in his villagisation project, their shared wider commitment to ujaama made them, at best, reluctant to see the failings of the scheme and, at worst, complicit in some of the abuses. As Adrian Moyes wrote of forced villagisation in 1975, 'in the long-run it will turn out to be right; without some such move the chance of building a better society was slipping away. ${ }^{60}$ The problematic involvement of Oxfam and Christian Aid in Tanzania has been set out at length by Michael Jennings, but here we can see how it diminished the type of aid appraisal that Llewellyn had long strove towards. ${ }^{61}$

It is not difficult to see how Llewellyn's phrase, the 'Oxfam bias', covers what others of a different scholarly persuasion might identify as the forms of governmentality that have as their effect the perpetuation of the very systems of which they are a part. ${ }^{62}$ But, importantly, these effects were also the products of the social interaction of individuals within an organisation concerned with the 'interpretation of events' through which success could be proclaimed. ${ }^{63}$ Field directors were unlikely to criticise partners on the ground they had worked with for many years. All individuals, as in any organisation, did not wish to readily admit that their professional efforts over many years had actually been of no real significance. Collectively, Oxfam staff focussed on one particular region, such as all those 
connected to the Africa Committee, had an interest in telling the Executive and Council of the good works being conducted in their area. And the nature of fundraising, which always sought out the success story to sell to a mass donating public, encouraged a type of field reporting that identified spectacular returns on the investment of altruism. No wonder, then, that when Llewellyn's more general observations on the need for greater planning and concentration of Oxfam's aid policy were actually discussed within all levels of the organisation, they came up against a range of other agendas, interests and predilections that meant his prescriptions were diluted, diverted or deferred. ${ }^{64}$

As early as mid-1970 Llewellyn had become disillusioned with his role. He wrote to Kirkley that, 'I've been in Oxfam long enough to recognize a peripheral activity when I see one. ${ }^{65}$ Persuaded on this occasion to stay in his post, he nevertheless remained concerned about his 'limited value' to Oxfam. ${ }^{66}$ He found it 'ludicrous' that he was supposedly a key part of the Overseas Aid Division yet knew he could simply be ignored and, as a consequence, 'served little useful purpose' other than the 'PR role in merely existing as a title'. ${ }^{67}$ Feeling his role to be too 'passive' he continued to be asked to be transferred to another position. ${ }^{68}$ Without a 'mandatory constraint' arising from his reports, which would have forced field directors to change their practices, his function was 'sterile'. ${ }^{69}$ At the end of 1973 he obtained his wish and he was allowed to become a consultant to the field directors operating in his beloved Asia, from which position he thought he could exercise greater influence through informal guidance of field staff. ${ }^{70}$

However, the problems he had identified with the optimism surrounding aid appraisal did not disappear. Llewellyn was succeeded in 1974 by the long-serving field director, Chris Howse, who was promoted to the adapted role of Evaluation Officer. ${ }^{71}$ His position, unlike Llewellyn's, was located within and not outside the Overseas Aid Division of the NGO. While this gave him better access to field directors and ensured his reports could not so easily be overlooked, it also meant he was subject to far more control than the free-ranging Llewellyn. His job description especially oriented him towards more positive ends. Instead of being able to identify what did not work, he was steered towards suggesting improvements, thereby working on the assumption that everything Oxfam was doing was worthwhile to some degree. ${ }^{72}$ It meant he aligned more closely with the more optimistic - and impressionistic - evaluations that others continued to make. In contrast to Llewellyn's dour opening to his tour reports, Howse was more likely to jauntily begin with a statement such as, 'the overall impression is one of considerable progress' ${ }^{73}$ 
Others reporting from the field also continued to offer the type of vague conclusion so disliked by Llewellyn. For all that appraisal was professionalised throughout the 1970s and beyond, Oxfam staff could still sign off reports with statements such as 'all are doing such a wonderful job of work. ${ }^{74}$ The future official historian of Oxfam, Maggie Black, wrote of her whistle-stop tour of Africa in the 1970s that she was impressed by all she saw, suggesting the world view of a tourist as much as a professional surveyor. ${ }^{75}$ Later, in 1983, Ian Somerville marvelled at everything Oxfam was doing in Kenya and Tanzania and in 1989 M. J. Butcher reported on just how hard at work everyone was in Oxfam's operations in Mali and Senegal. ${ }^{76}$ Even into the 1990s, in their reports to the various overseas committees, visitors from headquarters could prefer the chatty style of the spirited traveller than the sober prose of the clinical classifier of aid projects that was increasingly found across the sector. ${ }^{77}$

\section{Conclusion}

It needs to be emphasised that Oxfam was ahead of the curve on aid appraisal. For all the difficulties the organisation had in dealing with the consequences of Llewellyn's reports the fact is they did recognise the need for project assessment in 1968 and they did act upon it. This put the organisation alongside a handful of its larger counterparts elsewhere, such as CARE and the Red Cross, and showed an awareness of the need for evaluation expressed within the official development machinery. But it also put it ahead of its equivalents and competitors in Britain. At the time of Llewellyn's initial appointment, other charities did not prioritise appraisal to the same extent, else they simply lacked the resources to commit to staff not focussed on the immediate present or the near future. War on Want, Christian Aid and Save the Children had all not yet embarked on the forms of aid effectiveness testing that would increasingly come to the fore across the sector in later decades. Younger NGOs, too, such as Tearfund, were also not engaging in project appraisal, though here the reasons were also influenced by a commitment to only work with certain types of partner organisation. ${ }^{78}$

It was only at the end of the Freedom From Hunger Campaign that the need for project appraisal was made clear to the NGO sector. The FAO appointed J. A. Ponsioen of the Institute for Social Studies in The Hague to undertake a rudimentary assessment of the projects funded through FFHC. His conclusions were generally favourable, though he pointed to a list of problems of the sort Llewellyn had been articulating for some time. This prompted many within the NGO sector to push for further appraisal. In particular, Freddie Lees, 
secretary to the NGO umbrella body, VCOAD, believed that with total funds being expended by NGOs on development reaching $£ 700$ million by the end of the 1960 s, the lack of coordination across the sector and within organisations simply could not continue. ${ }^{79}$ Other NGOs then followed Oxfam's lead. Save the Children launched a full review of all aspects of its organisation in 1972 and by 1973 Christian Aid had commissioned an independent assessment of all the projects it funded in Botswana. ${ }^{80}$

Nevertheless, this ought not to make us believe that issues about the appraisal of aid have been resolved or that, through a reflection on the results of assessment, NGOs have been able to define better their humanitarian role. These debates have continued. Indeed, in 1987, Llewellyn finished his memoirs with a reflection on the purpose of aid that still recognised a 'modest role' for charities: 'the chief role of do-gooders was less to change the world than to prevent - if they could with the means to hand - things from getting any worse'. ${ }^{81}$ This was a sentiment unlikely to have chimed with his more ambitious colleagues in the 1960s and 1970s. But it was one that was quietly in accord with the 'do no harm' principle associated with the Quakers and which pervaded the early atmosphere of Oxfam. Moreover, it was one that has increasingly come to be put forward by the likes of humanitarian commentators such as David Reiff, who have sought to rein in NGOs from some of their more extensive roles, especially when aligned to the security agenda since the 1990s. Here, NGOs are to be praised for the practical work they can achieve, especially in relief and rehabilitation, but these authors doubt whether NGOs ought to be the agents to securing more ambitious ends, be it the end of poverty or the end of the abuse of human rights. ${ }^{82}$ As Llewellyn himself put it in 1972:

We should not reinforce the bias any further by making our decisions on the basis of optimistic assumptions about what is likely to happen, and call our attitude pragmatic. . . . we should make our greatest efforts to control what is primarily in our power to control (where we can be held accountable for results) and not spend too long in those rarefied uplands where the intangibles take over, the rose-tinted spectacles colour reality for us, and accountability is to God alone. ${ }^{83}$

The best account of the self-perpetuating nature of the development infrastructure remains Ferguson's detailed ethnography of Lesotho in the 1980s. He excluded NGOs from his account but Mann's more recent work on NGOs shows how they too can be incorporated into the interpretation. If we also follow Mosse's lead and add to the analysis an account of the social life of appraisal as various actors proclaimed a project's success then we can see 
how, even before the massive expansion of NGO activity after the 1970s, institutions on their own provided their own internal logics of governmentality. For an organisation such as Oxfam, rapidly expanding into the developing world and doing so assisted by staff in swiftly growing departments, various institutional and personal agendas clearly benefitted from a more optimistic assessment of what was taking place on the ground. Partners could be refunded, donors could be satisfied, field directors could be rewarded and staff at headquarters could further their careers. This is not to say that altruism did not reside behind any one of these motives. But it all served to focus attention on the expansion of Oxfam's activities rather than on the quality of the aid delivered.

It remains open to further discussion as to whether aid appraisal systems introduced after the 1970s and alongside the massive injections of funds from official sources into NGO income streams has answered many of the concerns Oxfam debated internally in the 1960s and early 1970s. But the point here is not really about whether aid appraisal improved. As Llewellyn's assessments and their social life within Oxfam demonstrate, it is less the quality of the appraisal made and more the history of how such reports were received and interpreted, that perhaps has more relevance to the NGO community today. No one within Oxfam seriously objected to what Llewellyn was doing or to his findings. But just about everyone that read his reports was able to dispute a detail and deliver a different overall view from the one he provided. This was the essential optimism that Llewellyn found within his 'bias'. He knew it was absolutely crucial to the maintenance of the good work that Oxfam and others were doing from the 1960s. But he knew too that it was crucial to the development of a system of 'nongovernmentality' that would help to consolidate the presence of NGOs across the developing world for many years to come. ${ }^{84}$ 
${ }^{1}$ James Ferguson, The Anti-Politics Machine: “Development”, Depoliticization, and Bureaucratic Power in
Lesotho (Minneapolis: University of Minnesota Press, 1994); David Mosse, Cultivating Development: An
Ethnography of Aid Policy and Practice (London: Pluto, 2005).
${ }^{2}$ Peter Burnell, Charity, Politics and the Third World (London: Harvester Wheatsheaf, 1991); Peter Burnell, Foreign Aid in a Changing World (Buckingham: Open University Press, 1997); Brian H. Smith, More than Altruism: The Politics of Private Foreign Aid (Princeton, NJ: Princeton University Press, 1990); Ian Smillie, The Alms Bazaar: Altruism Undr Fire - Non-Profit Organizations and International Development (London: IT Publications, 1995); Roger C. Riddell and Mark Robinson (eds.), Non-Governmental Organizations and Rural Poverty Alleviation (Oxford: Clarendon, 2001); Michael Edwards \& David Hulme (eds.), Making a Difference: NGOs and Development in a Changing World (London: Earthscan, 1992); Overseas Development Institute, The Impact of Overseas NGO Development Projects (London: ODI, 1996); Anthony J. Bebington, Samuel Hickey \& Diana C. Mitlin (eds.), Can NGOs Make a Difference? The Challenge of Development Alternatives (London: Zed, 2008); Diana Mitlin, Sam Hickey and Anthony Bebbington, 'Reclaiming development? NGOs and the challenge of alternatives', World Development, 35:10, 2007, pp. 1699-1720; Roger C. Riddell, Does Foreign Aid Really Work? (Oxford: Oxford University Press, 2007).

${ }^{3}$ Alan Fowler, Striking a Balance: A Guide to Enhancing the Effectiveness of Non-Governmental Organisations in International Development (London: Earthscan, 1997).

${ }^{4}$ Firoze Manji \& Carl O’Coill, 'The missionary position: NGOs and development in Africa', International Affairs, 78:3, 2002, pp. 567-83; Raymond L. Bryant, 'Non-governmental Organizations and Governmentality: 'Consuming' Biodiversity and Indigenous People in the Philippines', Political Studies, 50:2, 2002, pp. 268-292; Arturo Escobar, Encountering development: the making and unmaking of the Third World (Princeton, NJ: Princeton University Press, 1995); Janet G. Townsend, Gina Porter \& Emma Mawdsley, 'The role of the transnational community of non-governmental organisations: governance or poverty reduction?', Journal of International Development, 14, 2002, pp. 829-839; Mark Duffield, 'The liberal way of development and the development-security impasse: exploring the global life-chance divide', Security Dialogue, 41:1, 2010, pp. 5376; Terje Tvedt, Angels of Mercy or State-Financed Development Diplomats? NGOs and Foreign Aid (Oxford \& Trenton, NJ: James Currey \& Africa World Press, 1998).

${ }^{5}$ Gregory Mann, From Empires to NGOs in the West African Sahel: The Road to Nongovernmentality (Cambridge: Cambridge University Press, 2015).

${ }^{6}$ Kwame Nkrumah, Neo-colonialism: The Last Stage of Imperialism (London: Nelson, 1965); C. R. Hensman, Rich Against Poor: The Reality of Aid (London: Allen Lane, 1971); Teresa Hayter, Aid as Imperialism (Harmondsworth: Penguin, 1971).

Peter T. Bauer, Dissent on Development: Studies and Debates in Development Economics (London: Weidenfeld \& Nicholson, 1971); Peter T. Bauer, Equality, the Third World and Economic Delusion (London: Weidenfeld \& Nicholson, 1981).

${ }^{8}$ Robert Gillman Allen Jackson, A Study of the Capacity of the United Nations Development System (United Nations, 1969).

9 Maggie Black, 'Obituary: Bernard Llewellyn', Guardian, 24 June 2008, available at: http://www.theguardian.com/theguardian/2008/jun/24/1 [accessed 23 January 2015]; Maggie Black, A Cause for our Times: Oxfam, the First Fifty Years (Oxford: Oxford University Press \& Oxfam, 1992); 'The best of Oxfam: Bernard Llewellyn', Oxford Mail, 18 June 2008, available at: http://www.oxfordmail.co.uk/news/community/obituaries/obits/2350439. _The_best_of_Oxfam_/?ref=arc

[accessed 23 January 2015]. I am extremely grateful to Andrew Hicks, a friend of Bernard Llewellyn who is currently writing a biography of Llewellyn's close friend from the FAU, Jack Reynolds, author of $A$ Woman of Bangkok. He put me in touch with Bernard's son, Michael, who very kindly let me have access to the autobiography as well as some other materials: Bernard Llewellyn, Traveller in the Third World: The Memoirs of an Itinerant Do-Gooder, 1940-1982 (Unpublished manuscript, 1987).

${ }^{10}$ Mosse, Cultivating Development.

${ }^{11}$ Maggie Black, A Cause for our Times: Oxfam, the First Fifty Years (Oxford: Oxford University Press \& Oxfam, 1992), p. 74; Anna Bocking-Welch, "Imperial legacies and internationalist discourses: British involvement in the United Nations Freedom from Hunger Campaign, 1960-70," Journal of Imperial and Commonwealth History 40:5 (2012): 879-896; Mark Luetchford \& Peter Burns, Waging the War on Want: 50 Years of Campaign Against World Poverty (London: War on Want, 2003).

${ }^{12}$ Matthew Hilton, James McKay, Nicholas Crowson \& Jean-François Mouhot, The Politics of Expertise: How NGOs Shaped Modern Britain (Oxford: Oxford University Press, 2013).

${ }^{13}$ Matthew Hilton, 'Ken Loach and the Save the Children Film: humanitarianism, imperialism and the changing role of charity in postwar Britain', Journal of Modern History, 87:2, 2015, pp. 357-394.

${ }^{14}$ Cited in Ben Whitaker, Bridge of People: A Personal View of Oxfam's First Forty Years (London: Heinemann, 1983), p. 26. 
${ }^{15}$ Black, Cause for our Times, p. 192. On Llewellyn's own adventures in China see his Traveller in the Third World as well as his own travel writing: Bernard Llewellyn, I Left My Roots in China (London: Allen \& Unwin, 1953).

${ }^{16}$ Oxfam Mss. PRG 2/4/1: Bernard Llewellyn, 'Visit to Austria and Trieste, 10-20 May 1961', 30 May 1961.

${ }^{17}$ Ibid.

${ }^{18}$ Oxfam Mss. PRG 1/1/2: Bernard Llewellyn, 'Some additional notes', 24 August 1962.

${ }^{19}$ Oxfam Mss. PRG 2/4/1: Bernard Llewellyn, 'Visit to Algeria, 1-12 December 1962', 25 December 1962; Llewellyn, Traveller in the Third World, p. 67.

${ }^{20}$ Oxfam Mss. PRG 1/1/2: Oxfam FFHC Sub-Committee Minutes, 24 April 1962: Bernard Llewellyn, 'Trip to Hong Kong and Macau, 19-29 June 1962’.

${ }^{21}$ Oxfam Mss. PRG 2/4/1: Bernard Llewellyn, 'Tour of South East Asia - Part I: 17 July - 23 August 1964', 21 August 1964.

22 Oxfam Mss. PRG 2/4/1: Bernard Llewellyn, 'Visit to Korea, June 1965', 9 July 1965; Bernard Llewellyn, 'Visit to Korea, May - June 1964', 26 June 1964.

${ }^{23}$ Oxfam Mss. PRG 2/4/1: Bernard Llewellyn, 'Note following Pakistan trip, February - March 1966', 18 April 1966.

${ }^{24}$ Oxfam Mss. PRG 2/4/1: Bernard Llewellyn, 'Trip to the Near East, 5-24 March 1962', 2 April 1962; Black, Cause for Our Times, p. 134; Llewellyn, Traveller in the Third World, p. 70.

${ }^{25}$ Llewellyn, Traveller in the Third World, p. 135.

${ }^{26}$ Oxfam Mss. PRG 2/4/1: Bernard Llewellyn, 'Report on East Pakistan Cyclone Disaster, December 1965’, 27 December 1965.

27 Ibid.

${ }^{28}$ Oxfam Mss. PRG/2/4/1: Letter from Llewellyn to Kirkley, 15 July 1965.

${ }^{29}$ Oxfam Mss. PRG/1/1/3: Bernard Llewellyn ‘Overseas aid appraisal’, October 1968.

${ }^{30}$ Africa Field Committee: Richard Exley, 'A few observations on visits to Oxfam projects in Africa', 1 May 1964; T. H. G. Fletcher, 'Deputy Director's tour of East and Central Africa, 25 April - 3 June 1964', 11 Jun 1964; K. A. Bennett, 'West Africa, 14 Nov - 18 Dec 1964', 29 January 1965.

${ }^{31}$ Oxfam Mss. PRG/1/3/1: Africa Field Committee: C. M. Carruthers, 'Impressions and observations on Oxfam activities in relation to Central and Southern Africa', December 1965.

32 Oxfam Mss. PRG/2/4/1: Bernard Llewellyn 'Overseas aid appraisal', October 1968.

33 Oxfam Mss. PRG/1/3/2: Bernard Llewellyn, 'Visit to Kenya and Tanzania, November - December 1968', 3 January 1969.

${ }^{34}$ Bernard Llewellyn, With My Back to the East (London: Allen \& Unwin, 1958).

35 Oxfam Mss. PRG/2/4/1: Bernard Llewellyn, 'Visit to South Korea, August 1968', 3 October 1968.

${ }^{36}$ Oxfam Mss. PRG/1/3/1: Africa Committee Minutes, 20 November 1964.

${ }^{37}$ Oxfam Mss. PRG/1/3/3: Bernard Llewellyn, 'Visit to Malawi (May 1970)’, 11 June 1970.

${ }^{38}$ Ibid., p. 7

${ }^{39}$ Ibid.

${ }^{40}$ Michael Jennings, Surrogates of the State: NGOs, Development and Ujamaa in Tanzania (Bloomfield, CT: Kumarian, 2008).

${ }^{41}$ Oxfam Mss. PRG/2/4/1: Bernard Llewellyn, ‘Notes and queries on Oxfam’s aid programme’, April 1970.

42 Oxfam Mss. PRG/2/4/1: Bernard Llewellyn, 'Letter to the Director', 30 June 1970.

${ }^{43}$ Oxfam Mss. PRG/2/3/8/1: Internal Correspondence, Overseas Aid Director: Llewellyn, 'Notes for an overseas aid policy', 26 June 1969.

${ }^{44}$ Oxfam Mss. R8124: Executive Minutes: Llewellyn, 'Overseas aid appraisal', October 1968.

${ }^{45}$ Commission on International Development, Partners in Development (London: Pall Mall Press, 1969).

${ }^{46}$ Oxfam Mss. PRG/2/4/1: Bernard Llewellyn, ‘Notes and queries on Oxfam’s aid programme’, April 1970.

${ }^{47}$ Ibid.

48 Oxfam Mss. PRG/2/4/1: Bernard Llewellyn, ‘A query regarding Oxfam’s development role’, 4 February 1969.

49 Oxfam Mss. PRG/2/4/1: Bernard Llewellyn, ‘Oxfam’s aid programme - a personal view’, 23 February 1971.

50 Oxfam Mss. PRG/1/1/3: Bernard Llewellyn, ‘An analysis of Oxfam's aid objectives and some recommendations', May 1970.

51 Oxfam Mss. PRG/2/4/1: Bernard Llewellyn, 'The bias and its consequences - a discussion paper', 28 June 1972.

${ }^{52}$ Ibid.

53 Oxfam Mss. R8124: Executive Minutes, 23-24 October 1968: E.101/98 Overseas Aid Appraisal.

${ }^{54}$ Oxfam Mss. PRG/2/3/8/5: Executive \& Overseas Aid Committee, 'Overseas aid appraisal', 5 June 1969.

${ }^{55}$ Oxfam Mss. PRG/1/3/2: Letter from Malcolm Harper to Ken Bennett, 2 March 1969. 
${ }^{56}$ Oxfam Mss. PRG/1/3/3: Malcolm Harper, 'Synopsis of West Africa tour report, October/November 1971', May 1972.

${ }^{57}$ Oxfam Mss. PRG/1/3/3: Africa Committee Minutes, 24 June 1970; Malcolm Harper, 'Nairobi Office Annual Review, September 1968 - November 1969', November 1969.

${ }^{58}$ Oxfam Mss. PRG/1/3/3: Ben F. Brown, 'Oxfam in Nigeria', November 1973.

${ }^{59}$ Oxfam Mss. PRG/2/4/1: Bernard Llewellyn, 'An appraisal of the Oxfam Gramdam Action Programme in Bihar’, December 1970; Black, Cause for Our Times, p. 143.

${ }^{60}$ Oxfam Mss. PRG/1/3/4: Adrian Moyes, 'Two revolutions per year: a report of a visit to Chunya District, Tanzania', August 1975.

${ }^{61}$ Oxfam Mss. PRG/3/5/1: Iain Somerville, 'Tour report of Tanzania and Kenya, 9 September - 24 October 1983', 8 November 1983; OX Africa 105; Jennings, Surrogates of the State.

${ }^{62}$ M. Foucault, 'On governmentality', Ideology and Consciousness, 6, 1979, pp. 5-22; T. Johnson, 'Expertise and the state', in M. Gane \& T. Johnson (eds.), Foucault's New Domains (London: Routledge, 1993); M. Dean, Critical and Effective Histories: Foucault's Methods and Historical Sociology (London: Routledge, 1994), especially chapter 9, 'Governmentality ... .'; M. Dean, Governmentality: Power and Rule in Modern Society (London: Sage, 1999); Patrick Joyce, The Rule of Freedom: Liberalism and the Modern City (Verso, 2003); Nikolas Rose, 'Governing “advanced” liberal democracies', in A. Barry, T. Osborne and N. Rose (eds.), Foucault and Political Reason (London: UCL Press, 1996), pp. 37-64.

${ }^{63}$ Mosse, Cultivating Development, p. 8.

${ }^{64}$ Oxfam Mss. PRG/2/3/8/5: H. Leslie Kirkley, 'First draft of Director's paper to OAC 22.9.70: Some aspects of Oxfam's development progrmme'; Ken Bennett, 'Development programme', note to all field directors, 27 October 1970; Bernard Llewellyn, 'A further note on "Areas of concentration” and Devlopment Aid', note to Kirkley, 13 January 1971.

${ }^{65}$ Oxfam Mss. PRG/2/4/1: Bernard Llewellyn, ‘Letter to Director’. 30 June 1970.

${ }^{66}$ Oxfam Mss. PRG/2/4/1: Bernard Llewellyn, ‘A proposed modification of the Overseas Aid Appraiser', 9July 1971.

${ }^{67}$ Ibid.

${ }^{68}$ Oxfam Mss. PRG/2/4/1: Bernard Llewellyn, ‘Letter to Director’, 26 May 1972.

${ }^{69}$ Oxfam Mss. PRG/1/1/3: Bernard Llewellyn, 'Report of the Overseas Aid Appraiser’, 23 October 1973.

${ }^{70}$ Llewellyn, Traveller in the Third World, p. 148.

${ }^{71}$ Oxfam Mss. PRG/2/2/1: M. R . Harris, 'Evaluation Officer’, note to Field Directors, 8 August 1974.

${ }^{72}$ Ibid.

${ }^{73}$ Oxfam Mss. PRG/1/3/4: C. J. Howse, 'Zaire visit, 19-29 September 1975’, 8 October 1975.

${ }^{74}$ Oxfam Mss. PRG/3/5/1: Ian Moran and Douglas Holcroft, 'Report on overseas trip through Ghana and Togoland, 16 March - 8 April 1972’, 1972.

${ }^{75}$ Oxfam Mss. PRG/3/5/1: Maggie Black, Africa Tour Report', 25 September 1973.

${ }^{76}$ Oxfam Mss. PRG/3/5/1: Iain Somerville, 'Tour report of Tanzania and Kenya, 9 September - 24 October 1983', 8 November 1983; M. J. Butcher, 'Report on Tour to Mali and Senegal, 28 September - 17 October 1989', 1989.

${ }^{77}$ Oxfam Mss. PRG/3/5/1: Jane Holliday, ‘Tour report: Visits to Mauritania and Senegal, 2-6 February 1990.

${ }^{78}$ Hilton et al. Politics of Expertise.

${ }^{79}$ Oxfam Mss. PRG/2/3/10/36: F. Lees, 'The Problem of Overseas Project Co-ordination', 20 October 1970; VCOAD, Discussion of Project Co-ordination', 31 October 1970; Letter from Ken Bennett to Kirkley, 27 January 1971; Frederick lees, 'Aspects of the problem of coordinating NGOs' overseas programmes', 16 June 1971.

${ }^{80}$ Hilton, 'Ken Loach and the Save the Children Film'; Jim Flood, Reports on Development Projects Supported by Botswana Christian Council (London: Christian Aid, 1974).

${ }^{81}$ Llewellyn, Traveller in the Third World, p. 149

${ }^{82}$ David Rieff, A Bed for the Night: Humanitarianism in Crisis (2002:New York: Simon \& Schuster, 2003); Conor Foley, The Thin Blue Line: How Humanitarianism Went to War (London: Verso, 2008).

${ }^{83}$ Oxfam Mss. PRG/2/4/1: Bernard Llewellyn, 'The bias and its consequences', 28 June 1972.

${ }^{84}$ For an earlier use of the term 'nongovernmentality' see Matthew Hilton, 'Politics is ordinary: nongovernmental organisations and political participation in contemporary Britain', Twentieth-Century British History, 22, 2011, pp. 230-268. 